\title{
Studies on Electrical and Thermal Properties of Vinyloxyaminosilane Grafted Ethylene-Propylene-Diene Terpolymer/Linear Low Density Polyethylene Blends for Cable Applications
}

\author{
Muthukaruppan Alagar, ${ }^{\dagger}$ Moses Suresh Chandra Kumar, ${ }^{*}$ and Arun Anand PrabU \\ Department of Chemical Engineering, Anna University, Chennai 600025, India \\ ${ }^{*}$ Department of Chemistry, Scott Christian College, Nagercoil 629003, India
}

(Received April 1, 2002; Accepted October 1, 2002)

\begin{abstract}
A new terpolymer of vinyloxyaminosilane (VOS) grafted onto ethylene-propylene-diene terpolymer (EPDM) has been synthesised in a Haake Rheocord-90, torque rheometer. Vinyloxyaminosilane grafted ethylenepropylene-diene terpolymer/linear low density polyethylene (EPDM- $g$-VOS/LLDPE) blends with different compositions were prepared using a two roll mixing mill. The electrical properties such as surface and volume resistivities, dielectric strength and arc resistance are decreased and dielectric constant and dielectric loss are increased with increasing percentage composition of LLDPE in EPDM- $g$-VOS/LLDPE blends due to enhanced crosslink density. The incorporation of VOS moiety onto EPDM improves the inception decomposition and final decomposition temperatures due to stable three dimensional network and high bond energy of - $\mathrm{Si}-\mathrm{O}-\mathrm{Si}-$ linkage. The values of $T_{\mathrm{g}}$ are increased with increasing concentration of LLDPE in the EPDM- $g$-VOS/LLDPE blends due to enhanced crystallinity and crosslink density. Thermal aging studies on mechanical properties show that the tensile strength, elongation at break and Young modulus are decreased due to disruption of crosslinking at LLDPE sites.
\end{abstract}

KEY WORDS Vinyloxyaminosilane grafted Ethylene-Propylene-Diene Terpolymer/Linear Low Density Polyethylene (EPDM-g-VOS/LLDPE) Blends / Dielectric Strength / Arc Resistance / Dielectric Constant / Inception Decomposition / Thermal Ageing /

Synthetic polymers find number of applications in the field of electrical insulation, as molded components and as extruded cables. Crosslinking of thermoplastic polymers with organic and/or other curing agents leads to a three dimensional network structure having adequate thermal endurance properties coupled with good dielectric and mechanical properties. A good combination of flexibility and strength is an essential requirement of cable insulant. A continuous effort is being made to improve mechanical and thermal endurance properties of cable insulant without significant loss of dielectric characteristics. The advent of a newer technique, involving the grafting of silanes onto the polymer chain followed by its subsequent condensation reaction in the presence of moisture and catalyst is more attractive due to various advantages. The service life of cable insulant materials suffers from thermooxidative aging and degradation. Thermal stability of these polymers depends upon the type and nature of cross-link system.

The selection of polymeric insulating material for cable application depends upon various factors. ${ }^{1-3}$ Different thermal and electrical testing techniques are applied for quality checkup for cable materials. ${ }^{4-6}$ Cables for special applications areas such as resistance to oil, resistance to flame and fire requires specific character- istics. $^{7,8}$

Gartasegna ${ }^{9}$ developed low-voltage and mediumvoltage cable insulant products using vinyltrimethoxysilane (VTMO) grafted and moisture crosslinked ethylene-propylene copolymer (EPR) and ethylenepropylene-diene terpolymer (EPDM) and charecterised. Tanida et al. ${ }^{10}$ prepared heat shrinkable tubes by grafting vinyl trimethoxysilane (VTMO) with EPDM. Bustin Pierre et al. ${ }^{11}$ synthesised vinyltrimethoxysilane grafted EPDM and polyethylene using Brabender mixer. Kawada et al. ${ }^{12}$ prepared heat resistant silane grafted polymers with EPDM and other $\alpha$-olefins. Umeda et al. ${ }^{13}$ prepared composites exhibiting good processability and better thermal stability than original elastomers using silane grafted EPDM and the other $\alpha$ olefins with silica, stearic acid, antioxidant, zinc oxide and dicumyl peroxide. Zhang Yinxi et al..$^{14}$ investigated PVC/EPDM blends compatibilized by NBR-18 and reported that the blends exhibited excellent electrical insulation properties and good oil and low temperature resistance.

In the present work, a new terpolymer of vinyloxyaminosilane grafted ethylene-propylene-diene terpolymer (EPDM-g-VOS) has been developed and the grafted EPDM- $g$-VOS is blended with varying compositions of LLDPE. The blends were analysed by FT-IR

${ }^{\dagger}$ To whom correspondence should be addressed (E-mail: mkalagar@yahoo.com). 
spectroscopy. The electrical properties of the blends and the effect of blend composition on thermal degradation and thermal aging were studied in order to assess their utility for insulant cable applications.

\section{EXPERIMENTAL}

\section{Materials}

The EPDM (ENB) elastomer employed in this study was a commercial grade (Nordel IP 5750R) (ethylene/propylene/5-ethylidene-2-norbornene $=71 /$ $20 / 9$ by wt $\%$, with Mooney viscosity, $\mathrm{ML}_{(1+4)}$, of 50 at $125^{\circ} \mathrm{C}$ and specific gravity of 0.88 ) of DuPont Dow Elastomers, U. S. A. The vinyloxyaminosilane (VOS) $\left(M_{\mathrm{w}}=313\right.$, specific gravity $=0.988$, viscosity $=11.5 \mathrm{cP}$ and $\mathrm{bp}=300^{\circ} \mathrm{C}$ ) was procured from Wacker-Chemie, Germany. LLDPE (ethylene-1-octene) used was commercial grade (Engage 8003) with Mooney viscosity, $\mathrm{ML}_{(1+4)}$, of 22 at $121^{\circ} \mathrm{C}$, MFI $=1.0 \mathrm{dg} \mathrm{min}^{-1}$. and density $=0.880 \mathrm{~g} \mathrm{cc}^{-1}$. of DuPont Dow Elastomers, U. S. A. Dicumyl peroxide (DCP) $(99 \%$ assay with $\mathrm{mp}=$ $30{ }^{\circ} \mathrm{C}$ ) was obtained from Concord Chemical Industrial Co., Taiwan.

Preparation of EPDM-g-VOS. The EPDM (ENB) semi crystalline granules were coated with $0.2 \mathrm{wt} \%$ dicumyl peroxide (DCP) initiator dissolved in $2.0 \mathrm{wt} \%$ vinyloxyaminosilane (VOS). The treated elastomer was processed in a Haake Rheocord- 90, torque rheometer at $160^{\circ} \mathrm{C}$ for $6 \mathrm{~min}$ at $30 \mathrm{rpm}$.

Preparation of EPDM-g-VOS/LLDPE Blends.

The calculated amount of EPDM- $g$-VOS, $0.1 \mathrm{wt} \%$ dibutyltindilaurate (DBTD) and fixed amount of DCP $(1.0,2.0$, and $3.0 \mathrm{wt} \%$, based on the amount of EPDM$g$-VOS) were preblended in a two roll mixing mill at $80^{\circ} \mathrm{C}$ for $10 \mathrm{~min}$. Blends of EPDM- $g$-VOS with LLDPE were prepared on a two roll mixing mill (Nishimura 84.301 Type, Japan). The LLDPE was blended with EPDM- $g$-VOS with different concentrations of DCP in the molten state at $180^{\circ} \mathrm{C}$ for $15 \mathrm{~min}$. The compounding recipe of the blends are presented in Table I.

Preparation of Test Specimen. Test specimens for electrical studies were prepared using an electrically heated compression moulding machine with clamping pressure of $10 \mathrm{~kg} \mathrm{~cm}^{-2}$ at $180^{\circ} \mathrm{C}$ for about $10 \mathrm{~min}$. The compression moulded specimens of EPDM- $g$-VOS and EPDM- $g$-VOS/LLDPE were cured by immersing in boiling water for $2 \mathrm{~h}$.

\section{Measurements}

Fourier-Transform Infrared Spectroscopy. The grafting reaction was confirmed by Fourier-transform infrared (FT-IR) (Nicolet, IMPACT- 400) spectroscopy.
Table I. Compounding recipe for EPDM-g-VOS/LLDPE

\begin{tabular}{|c|c|c|c|}
\hline \multicolumn{4}{|c|}{ blends } \\
\hline Composition & EPDM-g-VOS & LLDPE & DCP $x$ \\
\hline $\mathrm{E}_{90} \mathrm{X}_{10(\mathrm{~L})}$ & 90 & 10 & 0 \\
\hline $\mathrm{E}_{75} \mathrm{X}_{25}$ (L) & 75 & 25 & 0 \\
\hline $\mathrm{E}_{50} \mathrm{X}_{50(\mathrm{~L})}$ & 50 & 50 & 0 \\
\hline $\mathrm{E}_{25} \mathrm{X}_{75(\mathrm{~L})}$ & 25 & 75 & 0 \\
\hline $\mathrm{E}_{10} \mathrm{X}_{90(\mathrm{~L})}$ & 10 & 90 & 0 \\
\hline $\mathrm{E}_{90} \mathrm{X}_{10(\mathrm{~V})}$ & 90 & 10 & 1 \\
\hline $\mathrm{E}_{75} \mathrm{X}_{25}(\mathrm{~V})$ & 75 & 25 & 1 \\
\hline $\mathrm{E}_{50} \mathrm{X}_{50}(\mathrm{~V})$ & 50 & 50 & 1 \\
\hline $\mathrm{E}_{25} \mathrm{X}_{75}(\mathrm{~V})$ & 25 & 75 & 1 \\
\hline $\mathrm{E}_{10} \mathrm{X}_{90(\mathrm{~V})}$ & 10 & 90 & 1 \\
\hline $\mathrm{E}_{90} \mathrm{X}_{10}(\mathrm{~V})$ & 90 & 10 & 2 \\
\hline $\mathrm{E}_{75} \mathrm{X}_{25}(\mathrm{~V})$ & 75 & 25 & 2 \\
\hline $\mathrm{E}_{50} \mathrm{X}_{50}(\mathrm{~V})$ & 50 & 50 & 2 \\
\hline $\mathrm{E}_{25} \mathrm{X}_{75}(\mathrm{~V})$ & 25 & 75 & 2 \\
\hline $\mathrm{E}_{10} \mathrm{X}_{90}(\mathrm{~V})$ & 10 & 90 & 2 \\
\hline $\mathrm{E}_{90} \mathrm{X}_{10}(\mathrm{~V})$ & 90 & 10 & 3 \\
\hline $\mathrm{E}_{75} \mathrm{X}_{25}(\mathrm{~V})$ & 75 & 25 & 3 \\
\hline $\mathrm{E}_{50} \mathrm{X}_{50}(\mathrm{~V})$ & 50 & 50 & 3 \\
\hline $\mathrm{E}_{25} \mathrm{X}_{75}(\mathrm{~V})$ & 25 & 75 & 3 \\
\hline $\mathrm{E}_{10} \mathrm{X}_{90}(\mathrm{~V})$ & 10 & 90 & 3 \\
\hline $\mathrm{E}_{(\mathrm{W})}$ & 100 & 0 & 0 \\
\hline$X_{(L)}$ & 0 & 100 & 0 \\
\hline $\mathrm{X}_{(*)}$ & 0 & 100 & 1 \\
\hline $\mathrm{X}_{(*)}$ & 0 & 100 & 2 \\
\hline $\mathrm{X}_{(*)}$ & 0 & 100 & 3 \\
\hline
\end{tabular}

aDCP concentration is based on $100 \mathrm{phr}$ of EPDM$g$-VOS. E: EPDM- $g$-VOS. X: LLDPE. (L): Linear (uncrosslinked). (V): Crosslinked by both DCP \& hot water. (*): Crosslinked by DCP only. (W): Crosslinked by hot water only.

The spectra for EPDM, LLDPE, EPDM- $g$-VOS, and EPDM- $g$-VOS/LLDPE blends were obtained using compression molded thin films while that of VOS was recorded using the liquid sample.

\section{Electrical Properties}

Volume and Surface Resistivities. The volume and surface resistivity of the molded specimens were measured as per ASTM D 257-83 using SIGMA MM 87, Million Mega Ohm Meter at $500 \mathrm{~V}$ for $60 \mathrm{~s}$ at room temperature. The diameter and thickness of the specimens used were $100 \mathrm{~mm}$ and $4 \mathrm{~mm}$ respectively.

Dielectric Strength. Dielectric strength of the molded specimens (diameter $100 \mathrm{~mm}$ and thickness $4 \mathrm{~mm}$ ) was measured according to ASTM D 149-87 using SHEARING BRIDGE, Vettiner, France (accuracy $0.08 \%)$ at $250 \mathrm{~V}$ and $50 \mathrm{~Hz}$.

Dielectric Constant and Loss Factor. Dielectric constant and loss factor of specimens were measured as per ASTM D 149-87 using SHEARING BRIDGE, 
Vettiner, France (accuracy $0.08 \%$ ) over the temperature range between $30^{\circ} \mathrm{C}$ and $150^{\circ} \mathrm{C}$ at $50 \mathrm{~Hz}$. The diameter and thickness of the specimens were $51 \mathrm{~mm}$ and $4 \mathrm{~mm}$ respectively.

Arc Resistance. Arc resistance of the molded specimens (diameter $100 \mathrm{~mm}$ and thickness $4 \mathrm{~mm}$ ) was measured according to ASTM D 495 using ARC RESISTANCE TESTER (Enamelled Wire Testing Equipments, Puna, India) at $250 \mathrm{~V}$ and $50 \mathrm{~Hz}$.

\section{Thermogravimetric Analysis}

Thermogravimetric analysis of different blends and pure components was carried out using a DuPont 951 TGA coupled with a 990 Thermal Analyzer in nitrogen atmosphere. Samples were scanned at a heating rate of $20{ }^{\circ} \mathrm{C} \mathrm{min}^{-1}$. The first derivative of the primary thermogravimetric curves were determined from tangents to the weight loss curves.

\section{Differential Scanning Calorimetry}

The thermal behavior of blends and pure components were studied using DSC-2920 Mettler thermal analyser (TA Instruments Inc., U. S. A). The samples were inserted into the apparatus at room temperature and immediately heated to $200^{\circ} \mathrm{C}$ at a rate of $40^{\circ} \mathrm{C} \mathrm{min}^{-1}$ and kept for $1 \mathrm{~min}$ at this temperature in order to remove the volatile impurities. The samples were quenched to $-80^{\circ} \mathrm{C}$ and then heated to $250^{\circ} \mathrm{C}$ at a heating rate of $5^{\circ} \mathrm{Cmin}^{-1}$.

\section{RESULTS AND DISCUSSION}

\section{Fourier-Transform Infrared Spectroscopy}

Figure 1 shows the FT-IR spectra of EPDM-gVOS/LLDPE blend $\left(\mathrm{E}_{75} \mathrm{X}_{25}\right)$ (a), EPDM- $g$-VOS (b), VOS (c), EPDM(d), and LLDPE(e). The IR spectrum of EPDM- $g$-VOS (Figure $1 \mathrm{~b}$ ) reveals: $-\mathrm{CH}_{2}$ rocking vibration at $1460 \mathrm{~cm}^{-1}$ and $-\mathrm{CH}_{3}$ symmetric bending vibration due to the propylene group at $1365 \mathrm{~cm}^{-1}$. However $\mathrm{C}-\mathrm{H}$ stretching vibration (vinyl) at $3265 \mathrm{~cm}^{-1}$, $\mathrm{C}=\mathrm{C}$ stretching vibration at $1663 \mathrm{~cm}^{-1}$ and $-\mathrm{CH}_{2}-$ wagging vibration of $\mathrm{Si}-\mathrm{CH}=\mathrm{CH}_{2}$ at $930 \mathrm{~cm}^{-1}$ of VOS (Figure 1c) are disappeared due to grafting of VOS with unsaturation or allylic positions present in the side chain of ENB of the EPDM. It is also noticed that the band intensity due to unsaturation $(>\mathrm{C}=\mathrm{CH}-$ ) present in the side chain of ENB termonomer of EPDM (Figure 1d) at $815 \mathrm{~cm}^{-1}$ is also decreased in Figure $1 \mathrm{~b}$. However the $\mathrm{Si}-\mathrm{O}$ stretching vibration at $1094 \mathrm{~cm}^{-1}$ is not affected. These observations support the fact that $>\mathrm{C}=\mathrm{CH}-$ is utilised for new chemical bond formation with VOS.

The FT-IR spectrum of crosslinked EPDM-g-

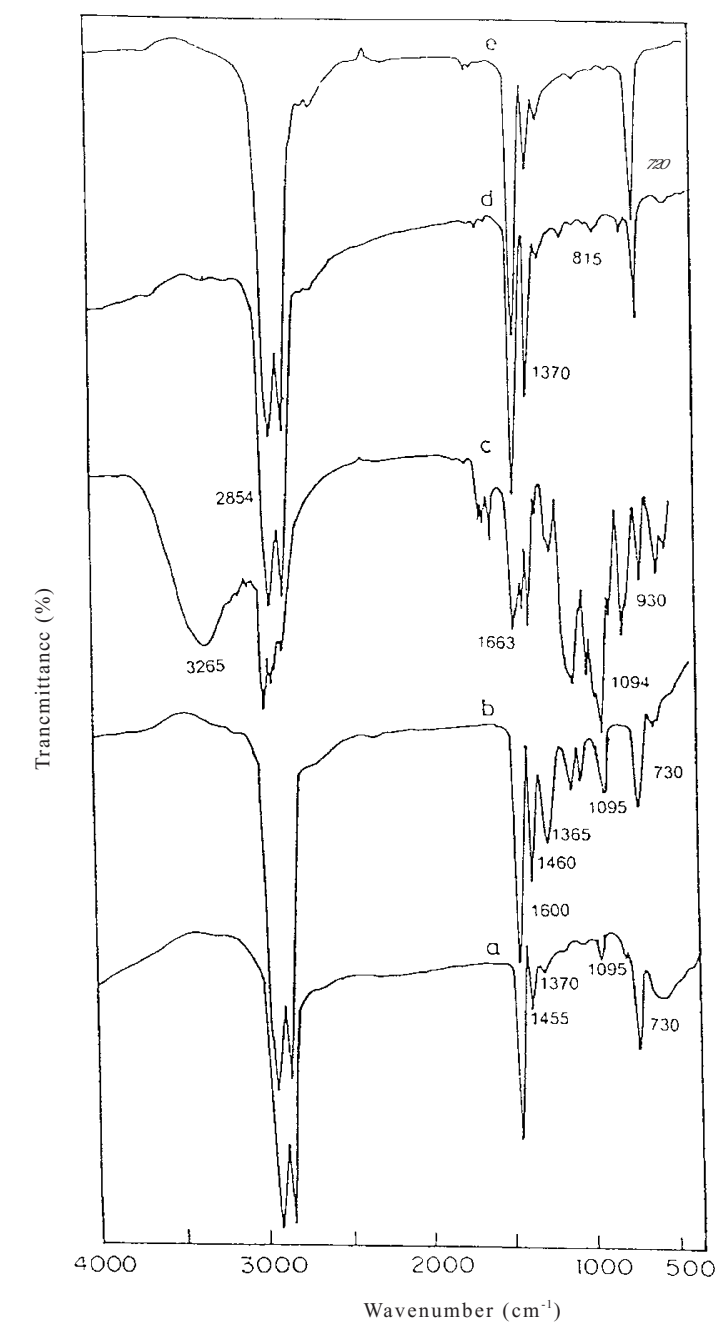

Figure 1. Infrared spectra of blends (a) $\mathrm{E}_{75} \mathrm{X}_{25}$, (b) EPDM-gVOS, (c) VOS, (d) EPDM, and (e) LLDPE.

VOS/LLDPE blend having composition $\mathrm{E}_{75} \mathrm{X}_{25}$ is presented in Figure 1a. The bands obtained are: $-\mathrm{CH}_{2}$ rocking vibration at $1455 \mathrm{~cm}^{-1},-\mathrm{CH}_{3}$ symmetric bending vibration at $1370 \mathrm{~cm}^{-1}$, and $-\left(\mathrm{CH}_{2}\right)_{n}$ - wagging vibration at $730 \mathrm{~cm}^{-1}$. A band at $1095 \mathrm{~cm}^{-1}$ due $\mathrm{Si}-\mathrm{O}$ stretching vibration clearly indicates the formation of $-\mathrm{Si}-\mathrm{O}-\mathrm{Si}-$ linkage in the blend.

\section{Electrical Properties}

Effect of LLDPE Concentration. The effect of LLDPE concentration on electrical properties such as volume resistivity, surface resistivity, dielectric constant, loss factor, dielectric strength and arc resistance of crosslinked EPDM- $g$-VOS, LLDPE, and blends of EPDM- $g$-VOS/LLDPE measured at room temperature and the results are presented in Table II. The electrical properties such as volume resistivity, surface resistivity, dielectric strength and arc resistance are decreased with increase in concentration of LLDPE in the blends due to increase of crosslink density associated with non-polar olefinic character. It is also observed that for, every 
Table II. Electrical properties of EPDM- $g$-VOS/LLDPE blends

\begin{tabular}{lcccccc}
\hline Composition & $\begin{array}{c}\text { Volume } \\
\text { resistivity } \\
(\mathrm{Ohm} \mathrm{cm}) \times 10^{12}\end{array}$ & $\begin{array}{c}\text { Surface } \\
\text { resistivity } \\
(\mathrm{Ohm}) \times 10^{12}\end{array}$ & $\begin{array}{c}\text { Dielectric } \\
\text { constant }\end{array}$ & $\begin{array}{c}\text { Loss } \\
\text { factor }\end{array}$ & $\begin{array}{c}\text { Dielectric } \\
\text { strength } \\
\left(\mathrm{V} \mathrm{mm}^{-1}\right)\end{array}$ & $\begin{array}{c}\text { Arc } \\
\text { resistance } \\
(\mathrm{s})\end{array}$ \\
\hline $\mathrm{E}(\mathrm{w})$ & 4.0 & 5.15 & 2.0 & 0.0022 & 760 & 130 \\
$\mathrm{E}_{90} \mathrm{X}_{10}(\mathrm{v})$ & 3.8 & 4.9 & 2.12 & 0.0025 & 750 & 127 \\
$\mathrm{E}_{75} \mathrm{X}_{25}(\mathrm{v})$ & 3.5 & 4.8 & 2.25 & 0.0029 & 724 & 123 \\
$\mathrm{E}_{50} \mathrm{X}_{50}(\mathrm{v})$ & 3.1 & 4.5 & 2.42 & 0.0034 & 678 & 118 \\
$\mathrm{E}_{25} \mathrm{X}_{75}(\mathrm{v})$ & 2.8 & 4.3 & 2.71 & 0.0038 & 633 & 115 \\
$\mathrm{E}_{10} \mathrm{X}_{90}(\mathrm{v})$ & 2.6 & 4.1 & 2.85 & 0.0040 & 610 & 112 \\
$\mathrm{X}(*)$ & 2.4 & 3.8 & 3.0 & 0.0042 & 590 & 110 \\
\hline
\end{tabular}

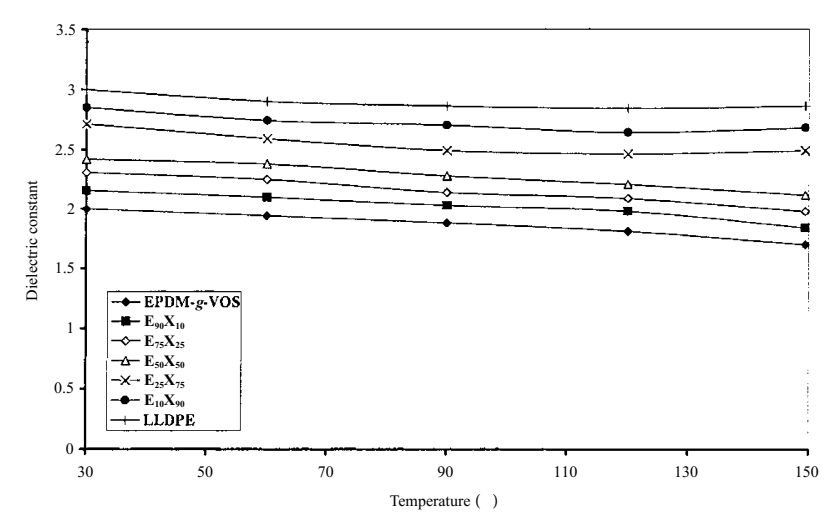

Figure 2. The plot of temperature variation $v s$. dielectric constant of EPDM- $g$-VOS/LLDPE blends.

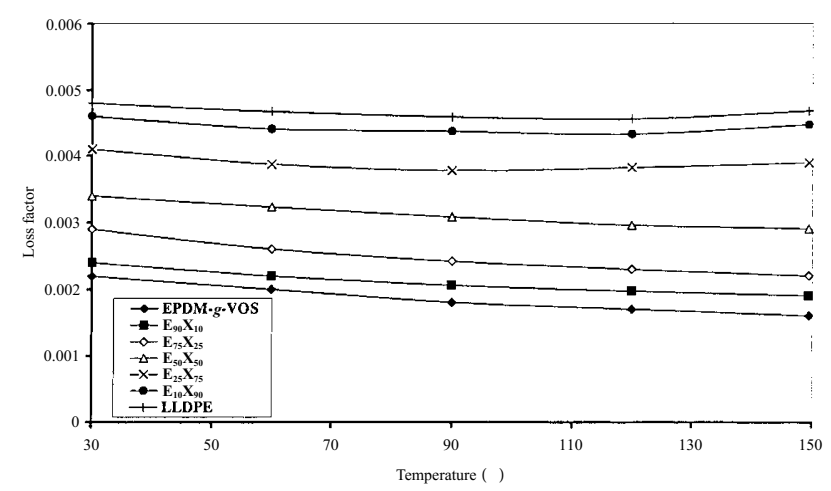

Figure 3. The plot of temperature variation versus loss factor of EPDM- $g$-VOS/LLDPE blends.

$50 \mathrm{wt} \%$ increase of LLDPE in the blend decreases the values of volume resistance to $20 \%$, surface resistivity to $10 \%$, dielectric strength to $12 \%$ and arc resistance by $7 \%$ respectively. However, dielectric constant and loss factor are increased by $17 \%$ and $23 \%$ respectively and this may be explained due to the inert hydrophobic nature imparted by LLDPE.

Effect of Temperature on Dielectric Constant and Loss Factor. The variation of dielectric constant and loss factor over a temperature range between $30^{\circ} \mathrm{C}$ and $150^{\circ} \mathrm{C}$ are studied for EPDM- $g$-VOS, LLDPE and EPDM- $g$-VOS/LLDPE blends and the results are presented in Figures 2 and 3. The value of dielectric constant decreases with increasing temperature and the de-

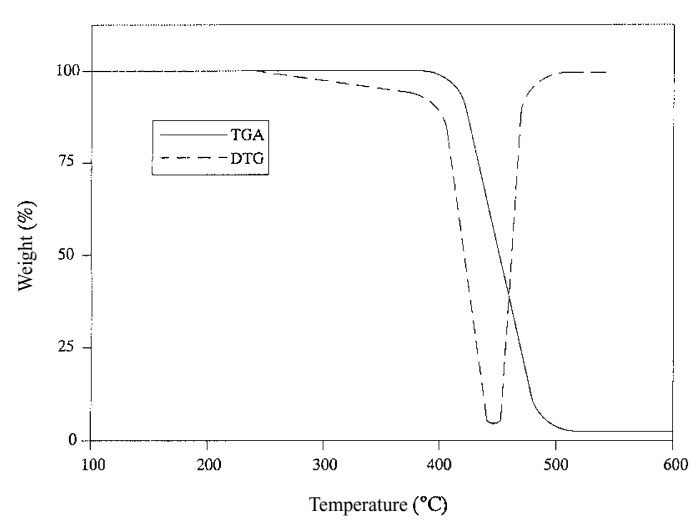

Figure 4. TG and DTG curves of peroxide cured EPDM.

Table III. Thermogravimetric analysis of EPDM- $g$-VOS/LLDPE blends

\begin{tabular}{lcccc}
\hline Composition & $\begin{array}{c}\text { Inception } \\
\text { temp. }\left(T_{\mathrm{i}}{ }^{\circ} \mathrm{C}\right)\end{array}$ & $\begin{array}{c}\text { Peak temp. Final temp. } \\
\left(T_{\mathrm{s}}{ }^{\circ} \mathrm{C}\right)\end{array}$ & $\begin{array}{c}\text { Weight } \\
\left(T_{\mathrm{f}}{ }^{\circ} \mathrm{C}\right)\end{array}$ & \begin{tabular}{c} 
loss $(\%)$ \\
\hline $\mathrm{E}(\mathrm{w})$
\end{tabular} \\
429 & 478 & 500 & 94 \\
$\mathrm{E}_{25} \mathrm{X}_{75}$ (v) & 345 & 468 & 482 & 96 \\
$\mathrm{E}_{50} \mathrm{X}_{50}$ (v) & 377 & 470 & 490 & 95 \\
$\mathrm{E}_{75} \mathrm{X}_{25}$ (v) & 420 & 474 & 498 & 94 \\
$\mathrm{X}(*)$ & 320 & 465 & 480 & 98 \\
\hline
\end{tabular}

crease in the value varies according to the nature of blend compositions. For example, the slope values obtained for blends of compositions $\mathrm{E}_{25} \mathrm{X}_{75}$ and $\mathrm{E}_{75} \mathrm{X}_{25}$ are 0.01 and 0.004 respectively. A similar trend is also noticed in the case of effect of temperature on the values of loss factor.

\section{Thermogravimetric Analysis}

Effect of VOS Grafting onto EPDM. Thermogram of peroxide cured EPDM at the heating rate of $20{ }^{\circ} \mathrm{C} \mathrm{min}^{-1}$ is presented in Figure 4. The inception decomposition temperature of hot water cured EPDM$g$-VOS is $3 \%$ higher than peroxide cured EPDM and the final decomposition temperature of EPDM- $g$-VOS is $4 \%$ higher than EPDM (Table III). The increase of inception decomposition and final decomposition temperatures of EPDM-g-VOS are due to the inclusion of silane (VOS) moieties through grafting which in- 


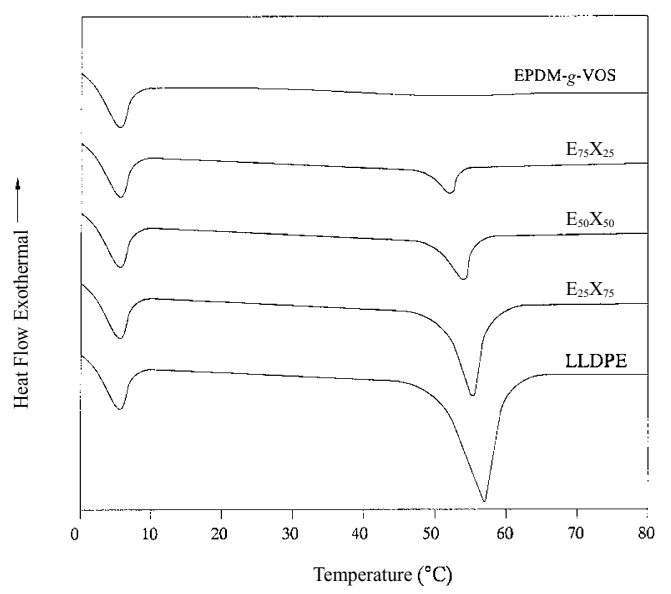

Figure 5. DSC curves showing the effect of blend composition on the melt characteristics.

turn enhances thermal stability due to the formation of stable three dimensional network and high bond energy values of $-\mathrm{Si}-\mathrm{O}-\mathrm{Si}-$ skeleton. The residue left after final decomposition temperature for EPDM and EPDM- $g$-VOS are $2 \%$ and $6 \%$ respectively. It is observed that EPDM- $g$-VOS has left higher proportion of residue than EPDM due to the formation of both siliceous $\left(\mathrm{SiO}_{2}\right)$ and carbonaceous materials whereas EPDM results only carbonaceous material.

Effect of EPDM-g-VOS Concentration. The influence of EPDM- $g$-VOS concentration on TGA decomposition curves of crosslinked EPDM-g-VOS/LLDPE blends of different compositions are presented in Table III. It is observed that for every $25 \mathrm{wt} \%$ increase of EPDM- $g$-VOS in the EPDM- $g$-VOS/LLDPE blends, the inception and final decomposition temperatures are increased to about $10 \%$ and $16 \%$ respectively due to the partial ionic character and high bond energy of $\mathrm{Si}-\mathrm{O}-\mathrm{Si}$ linkage. It is found that the negligible residual masses are obtained for the blends having composition $\mathrm{E}_{25} \mathrm{X}_{75}$, $\mathrm{E}_{50} \mathrm{X}_{50}$, and $\mathrm{E}_{75} \mathrm{X}_{25}$. From the TGA thermograms, it can be ascertained that there is a single stage degradation due to the scission of conjugated polyene chain and further this supports the fact that the these blends have single chemical entity.

\section{Differential Scanning Calorimetry}

Effect of LLDPE Concentration. The differential scanning calorimetry curves obtained for linear EPDM$g$-VOS, LLDPE, and EPDM- $g$-VOS/LLDPE blends are presented in Figure 5. The mid point of the transition in the DSC curves are recorded as glass transition temperature $\left(T_{\mathrm{g}}\right)$. The $T_{\mathrm{g}}$ values increased to about $5 \%$ for increase of every $25 \mathrm{wt} \%$ of LLDPE in the linear EPDM$g$-VOS/LLDPE blends due to improvement in crystallinity and increase in crosslink density. The downward peaks observed represents the crystalline melting
Table IV. Values of $T_{\mathrm{g}}$ and $T_{\mathrm{m}}$ of EPDM- $\mathrm{g}$-VOS/LLDPE blends

\begin{tabular}{lcc}
\hline Composition & $T_{\mathrm{g}}\left({ }^{\circ} \mathrm{C}\right)$ & $T_{\mathrm{m}}\left({ }^{\circ} \mathrm{C}\right)$ \\
\hline $\mathrm{E}(\mathrm{L})$ & -46 & - \\
$\mathrm{X}(\mathrm{L})$ & -55 & 57 \\
$\mathrm{E}_{25} \mathrm{X}_{75}(\mathrm{~L})$ & -53 & 55 \\
$\mathrm{E}_{50} \mathrm{X}_{50}(\mathrm{~L})$ & -50 & 53 \\
$\mathrm{E}_{75} \mathrm{X}_{25}(\mathrm{~L})$ & -48 & 51 \\
$\mathrm{X}(*)$ & -51 & 53 \\
$\mathrm{E}_{25} \mathrm{X}_{75}(\mathrm{v})$ & -48 & 51 \\
$\mathrm{E}_{50} \mathrm{X}_{50}(\mathrm{v})$ & -46 & 50 \\
$\mathrm{E}_{75} \mathrm{X}_{25}(\mathrm{v})$ & -42 & 48 \\
\hline
\end{tabular}

Table V. Crosslink density values of EPDM- $g$-VOS/LLDPE blends

\begin{tabular}{lcc}
\hline \multirow{2}{*}{ Sample Code } & \multicolumn{2}{c}{ Crosslink density $\times 10^{4}\left(\mathrm{gmol} \mathrm{cc}^{-1}\right)$} \\
\cline { 2 - 3 } & Unaged Blends & Aged Blends \\
\hline $\mathrm{E}(\mathrm{w})$ & 2.86 & 3.18 \\
$\mathrm{E}_{90} \mathrm{X}_{10}(\mathrm{v})$ & 2.93 & 3.12 \\
$\mathrm{E}_{75} \mathrm{X}_{25}(\mathrm{v})$ & 2.99 & 3.02 \\
$\mathrm{E}_{50} \mathrm{X}_{50}(\mathrm{v})$ & 3.07 & 2.98 \\
$\mathrm{E}_{25} \mathrm{X}_{75}(\mathrm{v})$ & 3.28 & 2.82 \\
$\mathrm{E}_{10} \mathrm{X}_{90}(\mathrm{v})$ & 3.44 & 2.76 \\
$\mathrm{X}(*)$ & 3.69 & 2.78 \\
\hline
\end{tabular}

points. However, crystalline melting point is absent in the case of EPDM- $g$-VOS due to its amorphous nature.

Effect of Crosslinking. The effect of crosslinking ( $2 \mathrm{wt} \%$ DCP and hot water) on glass transition temperature $\left(T_{\mathrm{g}}\right)$ and crystalline melting point $\left(T_{\mathrm{m}}\right)$ for blends having different compositions are presented in Table IV. The $T_{\mathrm{g}}$ values of crosslinked blends are higher than those obtained for linear blends due to increase of crosslink density by the introduction of network structure and it is also found that the crystalline melting point $\left(T_{\mathrm{m}}\right)$ of crosslinked blends are lower than the linear blends due to the disruption of crystal structure. The crosslink density of the unaged and aged samples are determined by swelling method. The samples are allowed to swell in Xylene at $120^{\circ} \mathrm{C}$ for $24 \mathrm{~h}$ and then dried to a constant weight in vacuum oven at $60^{\circ} \mathrm{C}$. The crosslink density of the samples are calculated using the formula proposed by Mark et al. The results are presented in Table V.

Thermal Ageing Characteristics. The effect of thermal ageing on the tensile properties of the samples measured as per ASTM D 412-87 using Universal Testing Machine (ZWICK- Model 1484) at a crosshead speed of $500 \mathrm{~mm} \mathrm{~min}^{-1}$. Test samples are subjected to ageing at $135^{\circ} \mathrm{C}$ and $200^{\circ} \mathrm{C}$ for different time intervals, viz., 50, 75, and $100 \mathrm{~h}$. The percent retention of tensile strength and elongation at break ob- 
Table VI. Retention of mechanical properties of hot water cured EPDM- $g$-VOS, DCP cured EPDM and both hot water and DCP cured EPDM- $g$-VOS/LLDPE blends after air ageing

\begin{tabular}{|c|c|c|c|c|}
\hline $\begin{array}{l}\text { Sample } \\
\text { Code }\end{array}$ & $\begin{array}{c}\text { Temperature } \\
\text { of ageing }\left({ }^{\circ} \mathrm{C}\right)\end{array}$ & $\begin{array}{c}\text { Time of } \\
\text { ageing }(\mathrm{h})\end{array}$ & $\begin{array}{l}\text { Percentage retention } \\
\text { of tensile strength }\end{array}$ & $\begin{array}{c}\text { Elongation } \\
\text { at break (\%) }\end{array}$ \\
\hline \multirow[t]{5}{*}{$\mathrm{E}(\mathrm{w})$} & 135 & 50 & -25 & -20 \\
\hline & & 75 & -40 & -30 \\
\hline & & 100 & -55 & -35 \\
\hline & 200 & 2 & -20 & -20 \\
\hline & & 3 & -35 & -40 \\
\hline \multirow[t]{5}{*}{${ }_{\operatorname{EPDM}}(\mathrm{c})$} & 135 & 50 & -30 & -40 \\
\hline & & 75 & -45 & -55 \\
\hline & & 100 & - & - \\
\hline & 200 & 2 & -25 & -30 \\
\hline & & 3 & -60 & -55 \\
\hline \multirow[t]{5}{*}{$\mathrm{E}_{25} \mathrm{X}_{75}(\mathrm{v})$} & 135 & 50 & -25 & -30 \\
\hline & & 75 & -40 & -55 \\
\hline & & 100 & - & - \\
\hline & 200 & 2 & -25 & -25 \\
\hline & & 3 & -55 & -50 \\
\hline \multirow[t]{5}{*}{$\mathrm{E}_{50} \mathrm{X}_{50}(\mathrm{v})$} & 135 & 50 & -25 & -25 \\
\hline & & 75 & -40 & -45 \\
\hline & & 100 & - & - \\
\hline & 200 & 2 & -20 & -25 \\
\hline & & 3 & -45 & -45 \\
\hline \multirow[t]{5}{*}{$\mathrm{E}_{75} \mathrm{X}_{25}(\mathrm{v})$} & 135 & 50 & -25 & -20 \\
\hline & & 75 & -40 & -35 \\
\hline & & 100 & -60 & -55 \\
\hline & 200 & 2 & -20 & -25 \\
\hline & & 3 & -40 & -40 \\
\hline
\end{tabular}

${ }^{2} \operatorname{EPDM}(\mathrm{C})$ : Crosslinked by DCP only.

tained after air ageing of silane crosslinked EPDM-gVOS, peroxide cured EPDM and both silane and peroxide crosslinked EPDM-g-VOS/LLDPE blends are presented in Table VI. From the data obtained from thermal ageing studies, it is ascertained that the retention of mechanical properties of silane cured blend systems are better than peroxide cured blend systems. The ageing resistance between silane and peroxide cured systems may be explained due to the formation of types of network structure and their stability. Peroxide crosslinking involves $\mathrm{C}-\mathrm{C}$ bond whereas silane crosslinking forms 3D Si-O-Si network structure. The 3D network structure involving siloxane linkage impart higher thermal stability than $\mathrm{C}-\mathrm{C}$ bond due to its high bond energy of $450 \mathrm{~kJ}$. The higher bond energy of $-\mathrm{Si}-\mathrm{O}-\mathrm{Si}-$ linkage results in higher stability against thermooxidative degradation and ageing. Moreover, in peroxide crosslinking, the formation of $\mathrm{C}-\mathrm{C}$ crosslinks results in the conversion of primary and secondary carbon atoms to secondary and tertiary carbon atoms respectively, which are more vulnerable to radical and oxidative attack. Similarly EPDM-g-VOS rich blends shows better air ageing resistant properties than LLDPE rich blends.

\section{CONCLUSION}

The grafting of VOS onto EPDM and the formation of stable $\mathrm{Si}-\mathrm{O}-\mathrm{Si}$ linkage through condensation of silane side chains in presence of hot water both in the cases of EPDM- $g$-VOS and EPDM- $g$-VOS/LLDPE have been confirmed from FT-IR spectra. The dielectric properties are decreased with increase in concentration of LLDPE in the EPDM- $g$-VOS/LLDPE blends due to enhanced crosslink density and non-polar character imparted by polyolefin molecular skeleton of LLDPE. The values of dielectric constant and loss factor are decreased with increasing temperature according to the blend compositions. The inclusion of silane (VOS) moiety in to EPDM and its blends increased the inception and final decomposition temperatures due to the formation of thermally stable three dimensional network through $\mathrm{Si}-\mathrm{O}-\mathrm{Si}$ bond. It is also observed that the inclusion of silane moiety in EPDM skeleton in EPDM$g$-VOS increases the insulating properties. EPDM$g$-VOS in the EPDM- $g$-VOS/LLDPE blends enhances the insulating behavior with reduction of mechanical 
properties according to the percentage composition. However, LLDPE rich blends exhibit better mechanical properties with little loss of electrical properties. From the data resulted from the experimental studies, it is concluded that the EPDM- $g$-VOS rich blends, viz., $\mathrm{E}_{75} \mathrm{X}_{25}$ and $\mathrm{E}_{90} \mathrm{X}_{10}$ can be utilized for low and medium high voltage cable insulation upto $35 \mathrm{kV}$.

\section{REFERENCES}

1. L. K. Djiauw and M. O. Westbrook, Wire J. Int, 20, 51 (1987).

2. T. M. Fischer, IEEE El Ins Mag, 5, 29 (1989).

3. S. Bhaumik and N. K. Datta, Plast. Rubb. Compos. Proc. Appl., 15, 39 (1991).

4. A. Tewarson, IEEE El Ins Mag, 6, 20 (1990).

5. S. Yasufuku, IEEE El Ins Mag, 6, 24 (1990).

6. J. M. Brun, IEEE El Ins Mag, 8, 27 (1992).
7. A. Pal, Kaut. Gumm. Kunst., 44, 958 (1991).

8. H. G. Dageforde, W. Berchem, and A. Mayer, Proccedings of the 31st International Wire and Cable Symposium, New York, U. S. A., January 6-7, 1982, p 401.

9. S. Garfasegna, Rubb. Chem. Technol., 59, 722 (1986).

10. M. Tanida and Y. Sato, Japanese Patent. JPS-61-76345 (Apr. 18, 1986).

11. B. Pierre, D. GuyPolart, J. Versyluijis, and J. Jacques, Belgium Patent B E 905048 (Nov. 03, 1986).

12. T. Kawada, M. Hikita, and K. Makino, Japanese Patent JPS63-225610 (Sep. 20, 1988).

13. I. Umeda, Y. Takemura, J. Watanabe, and Y. Funahashi, Japanse Patent JPS-63-72745 (Apr. 2, 1988).

14. Y. Zang, S. Han, X. Zhang, and W. Yang, Polym. Polym. Compos., 2, 181 (1994).

15. H. F. Mark, N. G. Gayload, and N. M. Biklas, "Encyclopedia of Polymer Science and Technology", Interscience, London, 1996, vol. 4, p 331. 